\title{
A FEASIBILITY STUDY OF SOLAR ENERGY-TECHNO ECONOMIC ANALYSIS FROM AKSARAY CITY, TURKEY
}

\author{
T. Taner ${ }^{1, *}$, A. S. Dalkilic ${ }^{2}$
}

\begin{abstract}
This study posed a feasibility study of solar energy-techno economic analysis that was investigated for $20,000 \mathrm{~m}^{2}$ area of Aksaray city from Turkey. The result of a solar energy radiation production was found to be 1.65 million $\left[\mathrm{kWh} / \mathrm{m}^{2}\right.$ year]. The profit of solar energy plant was determined about 501,825 [\$/y]. A simple payback period time was found to be $4.5[\mathrm{y}]$. The aim of the study is to indicate building solar energy plant that can be efficiently for Aksaray city. Since a solar energy plant can be a feasible plant for Yapilcan village, Aksaray city that is near the power line local area network. These results figure out very efficient result for building solar energy plant to Yapilcan village, Aksaray city from Turkey.
\end{abstract}

Keywords: Renewable Energy, Solar Energy, Techno Economic Analysis, Energy

\section{INTRODUCTION}

Over the years, most of countries need to product energy for their life and development. Thus, enhancement of sustainable energy works should be revealed by all countries. Hence, many countries try to progress renewable energy sources such as solar energy, wind energy, biomass, wave energy, fuel cell, hydrogen energy etc. Solar energy becomes an alternative energy that can be useful for all field of energy.

In literature, there are many previous studies. These literatures emphasize and describe a significant of solar energy.

Cetin and Egrican [1], who posed solar energy as future key roles for Turkey's energy, researched the employment effects of solar energy industry in Turkey.

Toklu [2] determined that solar energy could be used for biomass energy or auxiliary energy. Beside, apart from renewable energy, biomass is huge one that can be effectively stored solar energy.

Melikoglu [3] carried out the role of renewables and nuclear energy in Turkey's Vision 2023 energy targets for an economic and a technical research.

The combination of PV (photovoltaic) solar energy, a wind power plant and a PEM (Proton Exchange Membrane) fuel cell hybrid system were investigated for electrical power production by Devrim and Bilir [4].

Eksi and Karaosmanoglu [5] indicated about available heat sources of biomass involve solar for generation renewable energy.

Many previous studies also include solar energy with other renewable energy. Ozden and Tari [6], who studied other energy systems, researched a solar-hydrogen based hybrid renewable.

Badea et al [7] figured out a case study concerning a plant for hydrogen production using solar energy and technical analysis. Morcillo-Herrera et al [8] calculated the electricity generated by a photovoltaic cell.

In this study, we figure out solar energy plant that can be installed on a fertile land. Therefore, this plant can be appropriate to build a solar energy plant for Yapilcan Village on which solar radiation is a very high ratio and efficiently. Furthermore, this land is near the power line of local area network.

\section{FEASIBILITY OF SOLAR ENERGY PLANT'S PLACE}

Before the calculation of solar energy, the feasible of solar energy plant's place has to explain in a detailed way. Aksaray is located in Central Anatolia Region of Turkey.

Aksaray is the crossroads of Turkey as a location as well as history and culture. Not only Aksaray is located importance place but also its place includes energy and transportation issues. 


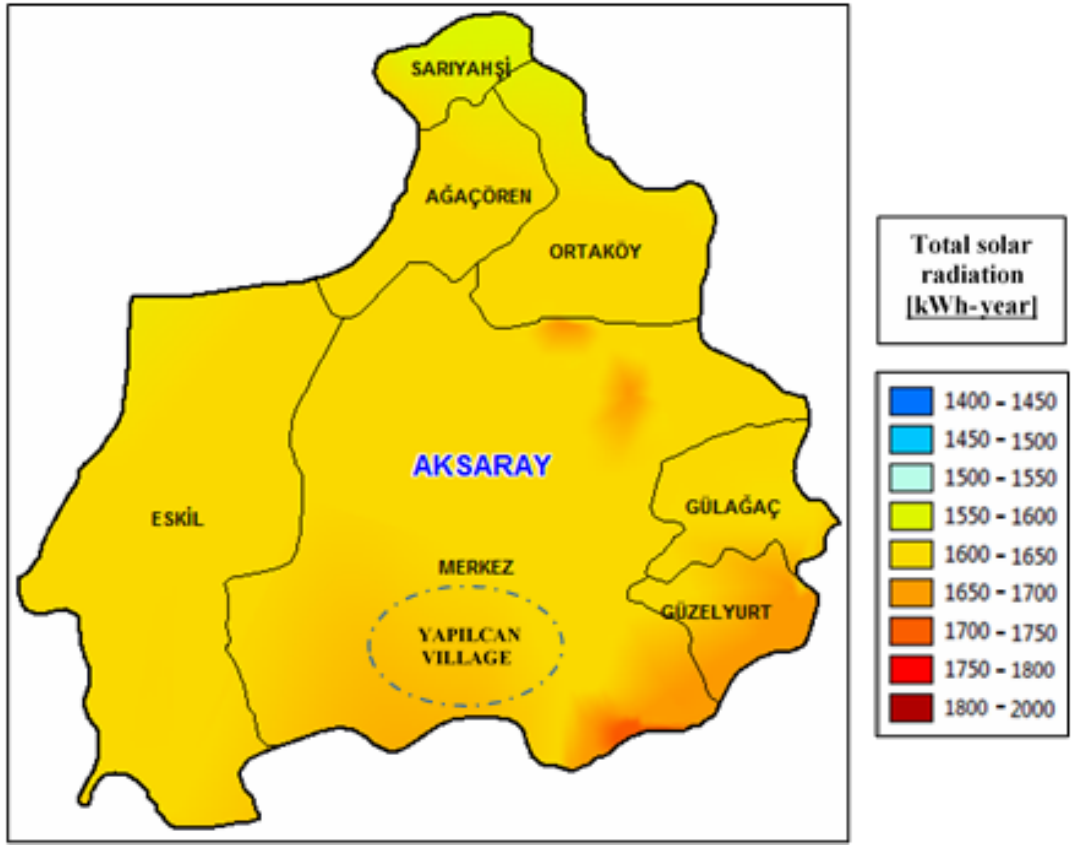

Figure 1. Total solar radiation of Aksaray city [9]

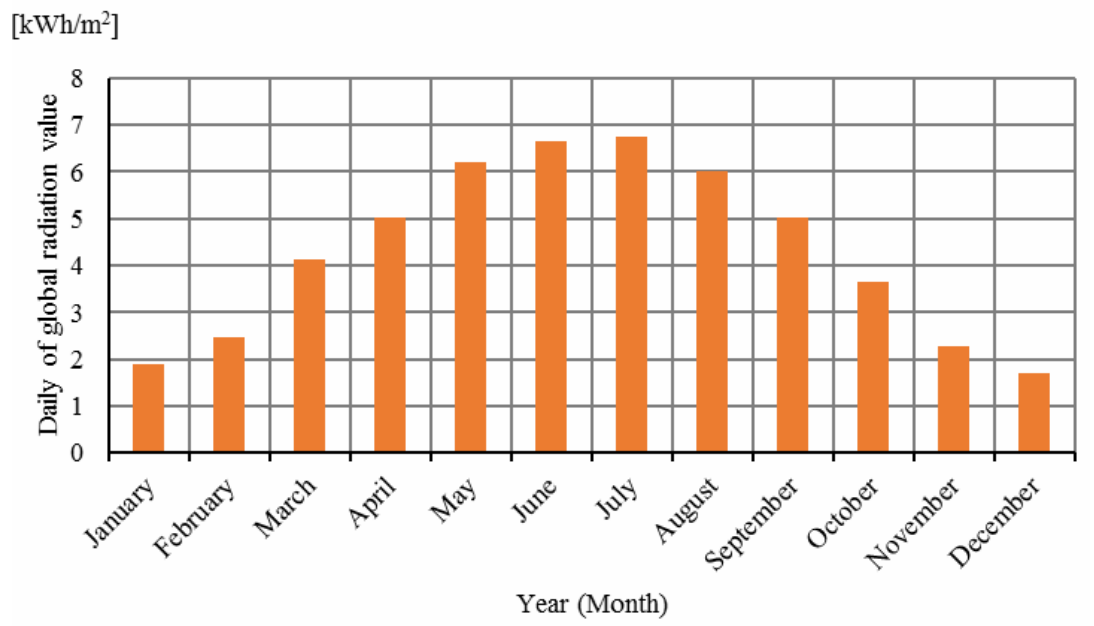

Figure 2. Daily global radiation value of Aksaray city [9]

Besides, Yapilcan Village, which is a district of Aksaray, is very suitable for building solar energy power plant due to the efficient of solar radiation. Thus, Yapilcan Village was chosen according to these reasons. These data and information of figures were taken from The Ministry of Energy and Natural Resources, General Directorate of Renewable Energy [9].

In Fig. 3, daily solar duration of Aksaray and PV type area - production of energy can be seen for a year. In this study, 20 decare of unproductive land was conducted for the solar power plant feasibility study. Solar energy panels of $20,000 \mathrm{~m}^{2}$ can be installed to benefit from unlicensed electricity generation legislation. 1 [MW] power can reach to $14,000\left[\mathrm{~m}^{2}\right]$ of this area, the result of which solar energy facility can be installed by using photovoltaic solar panel.

It is determined according to solar energy maps and other information from the town of Yapilcan where is a region with a solar radiation potential of $1650\left[\mathrm{kWh} / \mathrm{m}^{2}-\mathrm{y}\right]$. Furthermore, this region is close to the power distribution network. According to the Law No. 5346 of Renewable Energy Sources for Electricity Generation Production is presented in Table 1 below [9]. 


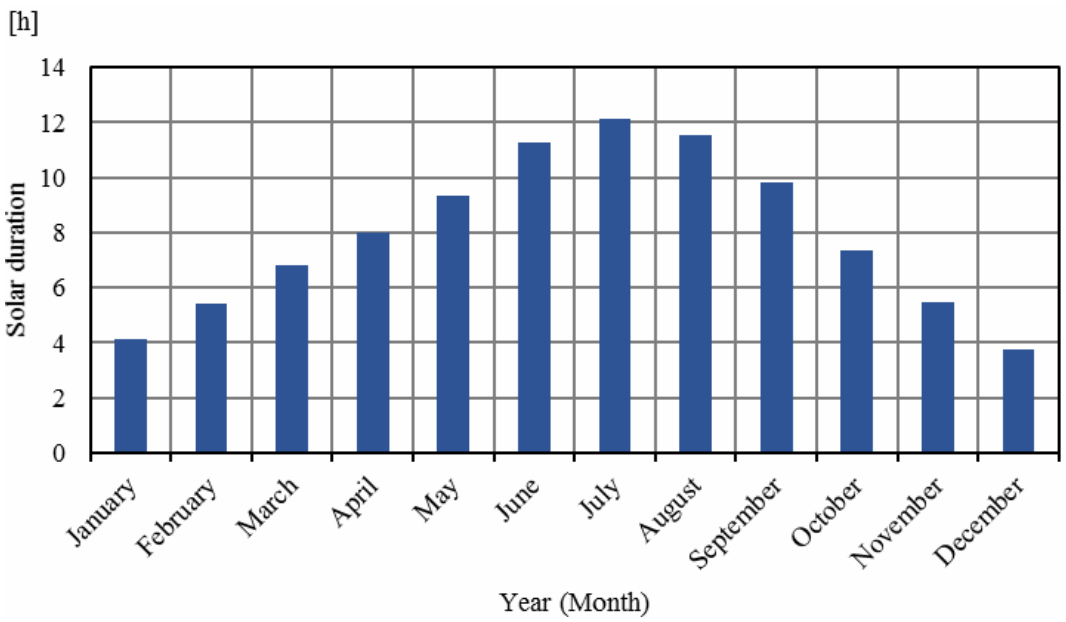

Figure 3. Solar duration of Aksaray city [9]

The production of an electricity sales price is 13.3 [ $\phi / \mathrm{kWh}]$ and construction of solar energy is 0.8 [ $\varnothing / \mathrm{kWh}]$ (A native construction). A native PV module that can be used, price is $1.3[\phi / \mathrm{kWh}]$. Accordingly, the total sales price of $15.4[\mathrm{~d} / \mathrm{kWh}]$ is realized in the form.

Table 1. Incentives of General Directorate of Renewable Energy

\begin{tabular}{|c|c|}
\hline Support (Incentives) & {$[\mathbf{c} / \mathbf{k W h}]$} \\
\hline Based on Solar Energy Production Facility Production & 13.3 \\
\hline Construction (native) & 0.8 \\
\hline PV Modules (native) & 1.3 \\
\hline Cells that make up the PV Module (native) & 3.5 \\
\hline Inverter (native) & 0.6 \\
\hline PV solar ray focusing device on Module (native) & 0.5 \\
\hline
\end{tabular}

Table 2. Facility investment cost of solar energy

\begin{tabular}{|c|c|}
\hline Facility investment cost of solar energy & {$[€ / \mathbf{W}]$} \\
\hline Solar panel & 0.56 \\
\hline Inverter & 0.20 \\
\hline Construct & 0.08 \\
\hline Wiring DC-AC & 0.06 \\
\hline Protect Equipment & 0.03 \\
\hline Transformer & 0.02 \\
\hline Other * & 0.06 \\
\hline Labor + Shipping & 0.07 \\
\hline Total Cost (Except Vat) & $1.08[€ / \mathrm{W}]$ \\
\hline Total Cost (Vat Included, 18\%) & $1.27[€ / \mathrm{W}]$ \\
\hline \multirow{2}{|c|}{ Note: *Remote Monitoring, } & $\mathbf{1 . 3 4}[\mathbf{\$} / \mathbf{W}]$ \\
\hline
\end{tabular}

According to the study, it can be estimated the facility investment cost of solar energy plant from Table 2 , respectively. Besides, some assumptions is approved and costs of the solar energy plant is determined considering the market conditions. Data of table is suitable for solar PV thin film that is taken from 1,300 [ $\$ / \mathrm{kW}]$ to $1,450[\$ / \mathrm{kW}][9,10,11,12]$. Total facility investment cost of solar energy was found around 1.34 [\$/W] equals to $1.34 \times 10^{6}[\$ / \mathrm{MW}]$.

In this study, solar energy and techno-economic was calculated respectively. An area of solar energy radiation can be calculated from Eq. 1 as follows [7, 8]: 
where $A_{r}$ is an area of solar energy radiation, $A_{T}$ is a total area and $R_{c}$ is efficiency of solar radiation. An annual production of solar energy radiation can be found from Eq. 2 as follows [7, 8, 13]:

$\mathrm{E}_{\mathrm{s}}[\mathrm{kWh} / \mathrm{y}]=\mathrm{Q}_{\mathrm{r}}\left[\mathrm{kWh} / \mathrm{m}^{2} \mathrm{year}\right] \times \mathrm{A}_{\mathrm{r}}\left[\mathrm{m}^{2}\right] \times 1,000$

where $E_{s}$ is an annual production of solar energy radiation and $Q_{r}$ is a ratio of solar energy radiation. An operation cost of solar energy plant can be calculated from Eq. 3 as follows:

$\mathrm{OC}[\$]=\mathrm{GTC}[\$ / \mathrm{kW}] \times 1,000[\mathrm{~kW}]$

where OC is an operation cost of solar energy plant and GTC is a general total cost of solar energy plant. A support price can be calculated from Eq. 4 as follows [7, 8, 13]:

$\mathrm{SP}[\$ / \mathrm{m}]=\mathrm{E}_{\mathrm{s}}[\mathrm{kWh} / \mathrm{m}] \times 1.3[-] \times \mathrm{PTC}[\$ / \mathrm{kWh}]$

where SP is a support price (incentive) from Turkish Government. PTC that is supported by Turkish Government according to 1,3 multiplier PV module native is 0.133 [ $\$ / \mathrm{kWh}]$.

Annual of the plant profit can be found from Eq. 5 as follows:

$\mathrm{PPA}[\$ / \mathrm{y}]=\mathrm{SP}[\$ / \mathrm{m}] \times \mathrm{n}[\mathrm{m} / \mathrm{y}]$

where PPA is an annual of plant profit and $\mathrm{n}$ is a year (12 months). Besides, energy consumption of solar energy plant was assumed $150,000[\mathrm{kWh} / \mathrm{m}]$. The cost of plant exempted tax was calculated $18,000[\$ / \mathrm{m}]$ for monthly.

Moreover, depreciation time can be estimated from Eq. 6 as follows:

$\mathrm{DT}[\mathrm{y}]=\mathrm{OC}[\$] / \mathrm{PPA}[\$ / \mathrm{y}]$

where DT is a depreciation time. If the operation of solar energy panel life is 25 years, profit time will be calculated an investment cost from Eq. 7 as follows:

$\operatorname{ADT}[y]=N_{h}[y]-D T[y]$

where ADT is a profit time (After investment cost) and $\mathrm{Nh}$ is an operation time of the solar power plant.

A solar energy power plant profit can be calculated a simple method in Eq. 8 as follows:

$\operatorname{PADT}[\$]=\operatorname{PPA}[\$ / y] \times \operatorname{ADT}[y]$

where PADT is a profit of solar power plant (After completed investment cost).

\section{RESULTS AND DISCUSSION}

The result of the study was posed in the summary of table. It can be seen clearly in Table 3 . In terms of Table 3, it was researched for 20,000 [ $\left.\mathrm{m}^{2}\right]$ area of Aksaray city from Turkey. The result of a solar energy radiation production annually was found 1.65 million $\left[\mathrm{kWh} / \mathrm{m}^{2} \mathrm{y}\right]$. This solar energy plant profit annual was calculated $501,285[\$ / y]$. A depreciation time was also found 6.7 year. Solar energy plant profit (PADT) was found around 9.1 million $[\$]$. 
Table 3. Result of the solar energy plant's techno economic analysis

\begin{tabular}{|c|c|c|}
\hline Feasibility of solar energy plant & Amount & Unit \\
\hline Solar energy production (Es) & $1,650,000$ & {$[\mathrm{kWh} / \mathrm{yr}]$} \\
\hline Operating costs (OC) & $1,340,000$ & {$[\$]$} \\
\hline Plant's cost (exempted) (PCE) & 18,000 & {$[\$ / \mathrm{m}]$} \\
\hline Supported price (SP) & 23,773 & {$[\$ / \mathrm{m}]$} \\
\hline Plant profit (PPA) & 501,285 & {$[\$ / \mathrm{y}]$} \\
\hline Payback period time: Depreciation time (DT) & 6.7 & year \\
\hline Profit time after investment cost (ADT) & 18.3 & year \\
\hline Solar energy plant profit (PADT) & $9,182,125$ & {$[\$]$} \\
\hline
\end{tabular}

According to the previous studies, payback period time was researched by Koppelaar [14], who determined payback period time as from 2 to 22 years from similar studies. Thakur and Chakraborty [15] found payback period time that was $8-10$ years.

In terms of the payback period result, result of our study is proper to similar previous similar studies. In that, we found payback period time (depreciation time) as 6.7 year. When we compared our result of payback period to similar previous studies, our result of the solar energy plant's payback period time can be seen very proper. Therefore, our study is suitable for building solar energy plant to Yapilcan village.

The cost of energy was compared to previous similar studies. IRENA Agency [11] determined the unit cost of solar energy around $1.4[\$ / \mathrm{W}]$ for $7\left[\mathrm{~m}^{2}\right]$ area. IRENA Agency [12] estimated the unit cost of solar energy from 1.35 [\$/W] to 1.56 [\$/W] for Europe. In our study, total facility investment unit cost of solar energy was found around $1.34[\$ / \mathrm{W}]$. The unit cost of energy can be seen suitable when comparing to the literature.

\section{CONCLUSION}

This study shows that a solar energy plant can be built on the land of Yapilcan village, Aksaray city that is near the power line local area network. These results are very proper, so the solar energy power plant can be installed Yapilcan village, Aksaray city from Turkey. According to the sunshine duration and solar radiation values, it is very important to have a value above the average of Turkey and to be in a position to invest solar power plants. Thus, the interest of native and foreign investors and the expectation of this interest can be increased this region in the future. There is a government support for the renewable energy law and for the equipment to be used in renewable energy plants to be produced in Turkey. Foreign and domestic investors can start their analysis work to establish solar energy fields.

The first investment cost of solar energy is being reduced by the enhancement of new works. In the coming period, renewable energy resources will be given importance by reducing the reserves of fossil fuels and increasing their costs. It is an environmental friendly energy and there is no harm to the environment. Solar energy can't be affected by the economic depression that could be caused by not being dependent on the outside in terms of raw material. This study indicated that Aksaray had to be evaluate for building solar energy plant to this region.

\section{ACKNOWLEDGEMENT}

The study that was designed a feasible solar energy plant for Yapilcan village land was requested to build solar energy plant by a firm. The study was also presented as a presentation at the International Conference on Energy and Thermal Engineering 2017, which was organized by Yildiz Technical University and held in Istanbul.

\section{NOMENCLATURE}

Ar solar energy radiation area, $\left[\mathrm{m}^{2}\right]$

AT total area, $\left[\mathrm{m}^{2}\right]$

$\mathrm{R}_{\mathrm{c}} \quad$ efficiency of solar radiation, [\%]

Es solar energy radiation production, $[\mathrm{kWh} / \mathrm{y}]$ 


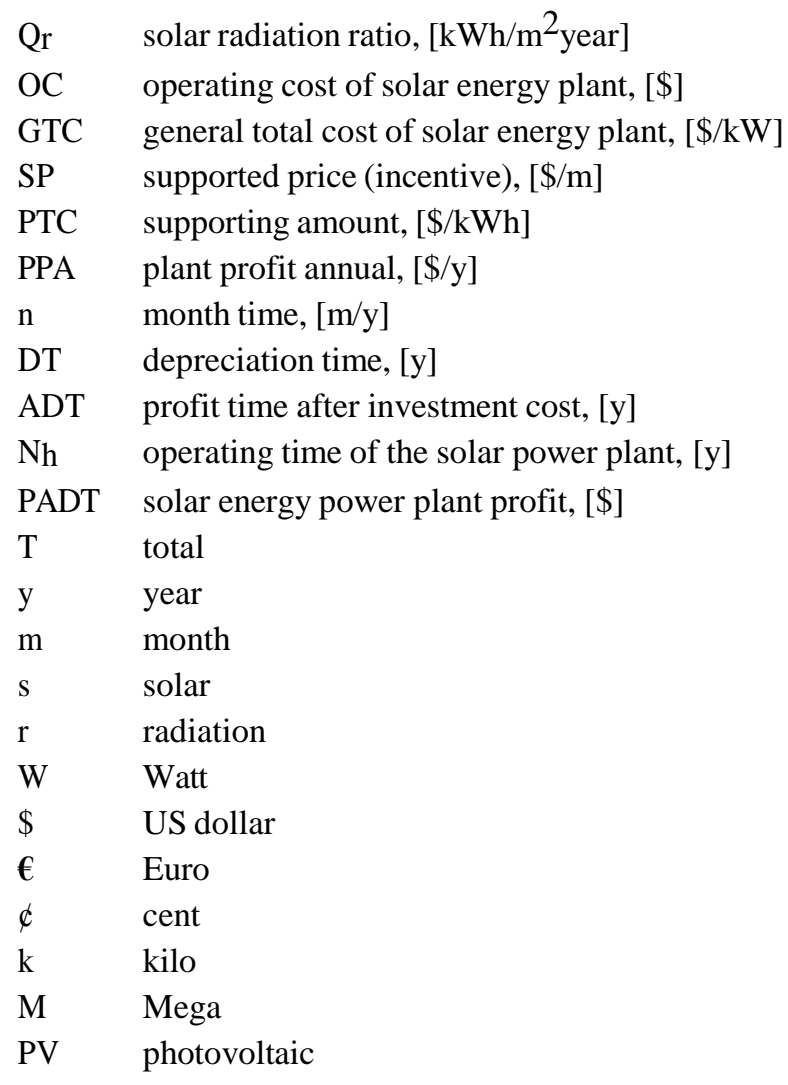

\section{REFERENCES}

[1] Çetin, M., Eğrican, N. (2011). Employment impacts of solar energy in Turkey. Energy Policy, 39(11), 71847190.

[2] Toklu, E. (2017). Biomass energy potential and utilization in Turkey. Renewable Energy, 107, $235-244$.

[3] Melikoglu, M. (2016). The role of renewables and nuclear energy in Turkey' s Vision 2023 energy targets: Economic and technical scrutiny. Renewable and Sustainable Energy Reviews, 62, 1-12.

[4] Devrim, Y., Bilir, L. (2016). Performance investigation of a wind turbine-solar photovoltaic panels-fuel cell hybrid system installed at İncek region-Ankara, Turkey. Energy Conversion and Management, 126, 759-766.

[5] Eksi, G., Karaosmanoglu, F. (2017). Combined bioheat and biopower: A technology review and an assessment for Turkey. Renewable and Sustainable Energy Reviews, 73, 1313-1332.

[6] Ozden, E., Tari, I. (2016). Energy-exergy and economic analyses of a hybrid solar-hydrogen renewable energy system in Ankara, Turkey. Applied Thermal Engineering, 99, 169-178.

[7] Badea, G., Naghiu, G. S., Giurca, I., Aşchilean, I., Megyesi, E. (2017). Hydrogen production using solar energy-technical analysis. Energy Procedia, 112, 418-425.

[8] Morcillo-Herrera, C., Hernández-Sánchez, F., Flota-Bañuelos, M. (2015). Method to calculate the electricity generated by a photovoltaic cell, based on its mathematical model simulations in MATLAB. International Journal of Photoenergy, 2015.

[9] The Ministry of Energy and Natural Resources (2017). General Directorate of Renewable Energy. Available from: http://www.eie.gov.tr

[10] Lazard's Levelized Cost of Energy Analysis, Version 8.0, 2016.

[11] International Renewable Energy Agency (IRENA). (2012). Renewable energy technologies: cost analysis series: Solar Photovoltaics, Volume 1: Power Sector Issue 4/5: 1-56.

[12] International Renewable Energy Agency (IRENA), Renewable power generation costs in 2014, 2015.

[13] Photovoltaic \& Solar Electricity Design Tools. Available from: www.photovoltaic-software.com, Access date: $14 / 06 / 2017$.

[14] Koppelaar, R. H. E. M. (2017). Solar-PV energy payback and net energy: Meta-assessment of study quality, reproducibility, and results harmonization. Renewable and Sustainable Energy Reviews, 72, 1241-1255.

[15] Thakur, J., Chakraborty, B. (2015). A study of feasible smart tariff alternatives for smart grid integrated solar panels in India. Energy, 93, 963-975. 